\title{
Atypical preeclampsia and eclampsia: report of four cases and review of the literature
}

\author{
Atipik preeklampsi ve eklampsi: dört vaka bildirimi ve literatürün gözden geçirilmesi \\ Mustafa Albayrak ${ }^{1}$, İsmail Özdemir ${ }^{1}$, Yavuz Demiraran², Süber Dikici ${ }^{3}$ \\ Duzce University School of Medicine 'Departments of Obstetrics and Gynecology and ${ }^{2}$ Anesthesiology and \\ Reanimation and Neurology, Düzce, Turkey
}

\section{Abstract}

Classically, most women who develop preeclampsia (hypertension and proteinuria) present some time after 20 weeks of gestation up to $48 \mathrm{~h}$ postpartum;and this is especially true in otherwise healthy, nulliparous pregnancies. Recent data suggest that in some women, preeclampsia and even eclampsia may develop in the absence of hypertension or proteinuria. Here, we report four atypical cases: eclampsia in the absence of hypertension and proteinuria (case 1), a partial seizure following eclampsia with antecedent proteinuria, but no hypertension (case 2), a case presenting with fetal distress, but no hypertension (case 3 ), and a case with unusually rapid progression and massive proteinuria that was unresponsive to therapy (case 4). Problems with atypical forms of eclampsia lie in its unpredictable onset; timely diagnosis and management are critical in avoiding complications. The purpose of this review is to increase the awareness of atypical forms of hypertensive disorders during pregnancy.

(J Turkish-German Gynecol Assoc 2010; 11: 115-7)

Key words: Atypical preeclampsia, atypical eclampsia

Received: 24 December, 2009

Accepted: 26 January, 2010

\section{Introduction}

The classic triad of preeclampsia is hypertension, proteinuria, and edema. Today, edema is no longer considered an important part of this condition, because it is a common finding in normal pregnancy, and approximately one-third of eclamptic women do not develop edema (1). In recent years, the new term "atypical preeclampsia-eclampsia" has been used to describe non-classical forms of hypertensive disorders arising during pregnancy (1-3). Although there is no strict definition of atypical preeclampsia-eclampsia, it has come to include cases with minimal or no proteinuria, but with hypertension, or proteinuria with no or marginally elevated blood pressure (BP), or without hypertension or proteinuria. Presentations before 20 weeks or more than $48 \mathrm{~h}$ postpartum, those resistant to $\mathrm{MgSO}_{4}$ therapy, and hemolytic anemia, elevated liver enzymes, and low platelets (HELLP) syndrome and its variants are also included in the atypical category (4) (Table 1). Atypical eclampsia constitutes about $8 \%$ of eclamptic cases (5). Problems with the atypical forms are their unpredictable onset and thus the difficulty in making a timely diagnosis

\section{Ozet}

Klinik olarak preeklampsi (hipertansiyon ve proteinüri) geliştiren çoğu kadında bulgular 20 gebelik haftasından postpartum 48 saate kadar ortaya çıkar ve bu özellikle diğer yönlerden sağlıklı nullipar gebelerde böyledir. Son bazı çalışmalarda preeklampsi ve hatta eklampsinin hipertansiyon ve proteinüri olmadan gelişebileceği gösterilmiştir. Burda biz dört atipik vaka takdim ettik: proteinüri ve hipertansiyon olmadan eklampsi (olgu 1), hipertansiyon olmaksızın proteinüriyi takip eden parsiyel eklampsi nöbeti (olgu 2), fetal distresle gelen ancak hipertansiyon olmayan bir vaka (olgu 3) ve hızlı gelişen tedaviye yanıt vermeyen masif proteinüri vakası (olgu 4). Atipik eklampsideki problem tahmin edilemeyen ortaya çıkışıdır, o nedenle zamanında tanı ve müdahale komplikasyonları engellemek için elzemdir. Bu yazının amacı gebelikteki atipik hipertansif durumlar hakkındaki bilinci arttırmaktır. (J Turkish-German Gynecol Assoc 2010; 11: 115-7)

Anahtar kelimeler: Atipik preeklampsi, atipik eklampsi

Geliş Tarihi: 24 Aralık 2009

Kabul Tarihi: 26 Ocak 2010

to initiate management, which is critical in avoiding complications. We present four cases of atypical preeclampsia/ eclampsia and discuss the challenges with these atypical forms, with an overview of the literature.

\section{Case 1}

A 20-year-old primigravida was hospitalized at 37 weeks with regular contractions. She had had irregular antenatal visits, which revealed no abnormality. She had a blood pressure (BP) between 130/80 and 100/60 mmHg on admission. Laboratory findings were unremarkable (hemoglobin $12 \mathrm{mg} /$ $\mathrm{dL}$, hematocrit: $37.2 \%$, thrombocyte: $122000 / \mathrm{mm}^{3}$, glucose: $70 \mathrm{mg} / \mathrm{dL}$, creatinine: 0.58, ALT: $31 \mathrm{U} / \mathrm{L}$, AST: $35 \mathrm{U} / \mathrm{L}, \mathrm{LDH}$ : $519 \mathrm{U} / \mathrm{L}$ ), with a trace of proteinuria in the urinalysis. She had no prodromes suggestive of hypertensive disease. She delivered a healthy female baby vaginally a few hours later, uneventfully. At $4 \mathrm{~h}$ after delivery, she developed a generalized convulsion, lasting $23 \mathrm{~min}$, despite being normotensive, and soon after this she had two other seizures. $\mathrm{MgSO}_{4}$ was given (loading dose of $46 \mathrm{~g}$ over $1520 \mathrm{~min}$, followed by a 
Table 1. Atypical preeclampsia (4)

\begin{tabular}{|c|}
\hline Gestational hypertension plus \\
\hline Mild symptoms of preeclampsia \\
\hline Thrombocytopenia \\
\hline Elevated liver enzymes \\
\hline Proteinuria plus \\
\hline Hemolysis \\
\hline Thrombocytopenia \\
\hline Elevated liver enzymes \\
\hline Early preeclampsia at $<20$ weeks \\
\hline Late postpartum preeclampsia/eclampsia \\
\hline HELLP, ELLP, and EL syndromes \\
\hline
\end{tabular}

maintenance dose of $2 \mathrm{~g} / \mathrm{h}$ as a continuous intravenous infusion). Following the seizures, her BP ranged between 140/90 and 100/60 mmHg. Slight increases in the liver function tests and LDH values and slight decreases in hemoglobin and platelets were detected (hemoglobin $10.3 \mathrm{mg} / \mathrm{dL}$, hematocrit 31.5\%, platelets $91,000 / \mathrm{mm}^{3}$, alanine aminotransferase (ALT) $35 \mathrm{U} / \mathrm{L}$, aspartate transaminase (AST) $66 \mathrm{U} / \mathrm{L}$, lactate dehydrogenase (LDH) $932 \mathrm{U} / \mathrm{L}$ ). Computed tomography (CT) was completely normal. Subsequently, she had three more seizures and another 2-g bolus of $\mathrm{MgSO}_{4}$ was infused over $35 \mathrm{~min}$ and continued for the following $24 \mathrm{~h}$, during which she suffered no further convulsion. The next day, a $24 \mathrm{~h}$ urine sample revealed $330 \mathrm{mg}$ proteinuria; cranial magnetic resonance imaging (MRI) showed no abnormality.

\section{Case 2}

A 20-year-old nulligravida was admitted with regular contractions at 37 weeks gestation. All her prenatal visits had been normal, including BP, which was recorded as $120 / 80$ to $110 / 70$ $\mathrm{mmHg}$. There was no prodrome of hypertensive disease and no laboratory abnormality, including platelet count, liver enzymes, $\mathrm{LDH}$, electrolytes, and glucose, although proteinuria $(3+)$ on dipstick was noticed on admission. She delivered a $2800-\mathrm{g}$ male fetus vaginally, uneventfully. Following the delivery, her BP increased suddenly to $150 / 100$ to $140 / 100 \mathrm{mmHg}$. Then, she had a generalized seizure lasting 5-10 s. Then, $2 \mathrm{~h}$ later, she developed sudden blindness, an occipital headache, and myoclonic seizures, particularly involving the right upper extremity. The postictal BP was around 160/120 mmHg. $\mathrm{MgSO}_{4}$ was given for $24 \mathrm{~h}$ as the patient seemed to have atypical eclampsia. She had no seizure subsequently. Her BP remained high for a few days, ranging between 150/100 and 140/90 $\mathrm{mmHg}$ and normalized on postpartum day 3, with $930 \mathrm{mg} / \mathrm{dL}$ proteinuria in the $24 \mathrm{~h}$ urine collected postpartum. Cranial MRI was unremarkable. On postpartum day 4 , she was discharged with her baby.

\section{Case 3}

A 31-year-old multipara presented with contractions at 33 weeks gestation with the cervix $2 \mathrm{~cm}$ dilated and $40 \%$ effaced.
Her BP was $110 / 70$ to $110 / 60 \mathrm{mmHg}$ on admission. Her CBC, routine biochemical tests, and coagulation studies were normal, but she had a dipstick proteinuria of $3+$. On admission, the intrapartum fetal heart rate recording revealed poor variability and late decelerations. An emergency Cesarean delivery was performed for fetal distress and a male fetus weighing $1900 \mathrm{~g}$ was delivered with APGAR scores of 4 and 6 at 1 and 5 min, respectively. The baby was admitted to the intensive care unit for respiratory distress syndrome. The placenta was atrophic, but not abrupted. Then, $2 \mathrm{~h}$ postoperatively, the mother became hypertensive, with a BP of $160 / 100$ to $150 / 100 \mathrm{mmHg}$, a severe headache and visual blurring. $\mathrm{A} \mathrm{MgSO}_{4}$ infusion was started with a loading dose $4.5 \mathrm{~g}$ over 20 minutes, followed by a maintenance dose of $2 \mathrm{~g} / \mathrm{h}$ as a continuous intravenous infusion for $24 \mathrm{~h}$. Three days later, she became normotensive and her complaints resolved. She was discharged on the $4^{\text {th }}$ postoperative day.

\section{Case 4}

A 24-year-old primigravida patient was admitted at 30 weeks gestation with suspected preeclampsia. She had 1+ proteinuria on dipstick and a BP of 110/70 to 140/90 mmHg. Her $24 \mathrm{~h}$ proteinuria was $440 \mathrm{mg} / \mathrm{dL}$. She was discharged 2 days later with a diagnosis of mild preeclampsia, to be followed as an outpatient. Four days later, she was readmitted with a BP of 190/120 mmHg measured at home. On readmission, her $\mathrm{BP}$ ranged between $120 / 90$ and $170 / 110 \mathrm{mmHg}$, with most values below 140/90 $\mathrm{mmHg}$. She had $3+$ proteinuria, a reactive non-stress test, and normal amniotic fluid volume and Doppler indexes. She had no symptom or laboratory abnormality. On the day of readmission, she had eclampsia and the fetus was lost in utero. Labor was induced with a 50 mcg misoprostol intravaginally, but $6 \mathrm{~h}$ later she had nine convulsions despite the $\mathrm{MgSO}_{4}$ infusion. Subsequently, she underwent delivery by Cesarean section under general anesthesia, due to failure of induction, and she was anesthetized for $24 \mathrm{~h}$ in the intensive care unit postoperatively. She had normal CT and a calculated proteinuria of $36 \mathrm{~g} / 24 \mathrm{~h}$. After weaning from the ventilator on the second day, she continued to convulse in the intensive care unit. However, she had no further convulsions from $48 \mathrm{~h}$ after awakening and was transferred to a normal ward and discharged 6 days later.

\section{Discussion}

The classic teaching that eclampsia is the end point of a disease process, starting subclinically and proceeding to mild preeclampsia and then severe preeclampsia implies that hypertension and proteinuria should precede the onset of eclampsia. In contrast to this paradigm, eclampsia can potentially be encountered at the beginning of the disease process before hypertension and proteinuria develop. Consequently, the term 'preeclampsia' has been criticized as misleading (6). In classic cases, the disease usually first involves the arteries and kidneys, manifesting as hypertension and proteinuria before other organ systems are involved. In atypical cases, however, the organ involvement may start with other systems, such as cerebral involvement, which presents initially as eclampsia. In our first, second, and third cases, the first mani- 
festation of the preeclampsia before hypertension or proteinuria was cerebral, renal, and placental involvement, respectively. This indicates that signs and symptoms of organ system involvement should be sought vigilantly in the absence of hypertension or proteinuria in suspected cases. Thus, these women should be seen frequently, at least twice weekly (4). Rather than relying solely on the presence of hypertension or proteinuria, the patient history, physical examination, and laboratory and imaging studies may be critical in not missing atypical forms (7). Suspicious findings may include marginally elevated BP or liver enzymes, fetal distress, blurred vision, and headache. The initial diagnosis should be atypical preeclampsia and eclampsia when suspected; timeconsuming diagnostic investigations for a differential diagnosis should be deferred until the patient is stabilized. A management plan should be started immediately for atypical forms, rather than searching for a rare disease in a differential diagnosis (Table 2) (8). Even a minor sign, such as the trace proteinuria in our first case, should not be overlooked and could be alarming in the absence of overt hypertension and proteinuria. In the second case, if the proteinuria per se had alarmed us earlier, despite the absence of hypertension, the patient could have been watched more closely for a postpartum rise in $\mathrm{BP}$ and pain management might have prevented the sudden increase in BP that provoked the convulsion. The absence of classic features results in unnecessary consultations and investigations or a delay in diagnosis and $\mathrm{MgSO}_{4}$ infusion. This is especially true for healthcare providers unfamiliar with atypical forms of eclampsia.

The rapidly progressive case of eclampsia in our fourth case was another example of an atypical form. She progressed to severe preeclampsia in four days and had resistant eclampsia, unresponsive to anticonvulsive therapy. This patient is a typical case of non-preventable eclampsia, because her convulsions could not be predicted or prevented even under hospital care. Sibai et al. reported that 56 of 179 cases of eclampsia were potentially unavoidable, despite proper antenatal care and management. Of the 56 patients, 24 convulsed, despite a recent prenatal visit with no previous hypertension, proteinuria, or symptoms suggestive of the forthcoming eclampsia (9). The extension of this series to 254 eclamptic cases found that 80 patients (32\%) did not have edema, 58 (23\%) had minimal or no hypertension, and 49 (19\%) did not have proteinuria at the time of convulsions (10). In a comprehensive study of 383 eclamptic women in the United Kingdom, 38\% of the eclamptic convulsions occurred before the documentation of proteinuria and hypertension and 75\% developed in hospital, while under supervision (6). These findings reflect the challenges in the early recognition and management of atypical presentations.

The most common cause of convulsions in association with hypertension or proteinuria during pregnancy or immediately postpartum is eclampsia. However, late postpartum eclampsia is defined as eclampsia that occurs more than $48 \mathrm{~h}$, but less than four weeks, after delivery (2). All patients with atypical-onset eclampsia should undergo a neurological evaluation to rule out the presence of neurologic causes of seizures (Table 2). Cerebral imaging is indicated for patients with focal neurologic signs, such as hemiparesis, an unconscious state, and prolonged coma. Additionally, cerebral imaging may be helpful in patients who have an atypical presentation of eclampsia (onset before
Table 2. Differential diagnosis of eclampsia (8)

\begin{tabular}{|l|}
\hline Cerebrovascular accidents \\
\hline Hemorrhage \\
\hline Ruptured aneurysm \\
\hline Arterial embolism or thrombosis \\
\hline Cerebral venous thrombosis \\
\hline Hypoxic ischemic encephalopathy \\
\hline Angiomas \\
\hline Hypertensive encephalopathy \\
\hline Seizure disorders \\
\hline Previously undiagnosed brain tumors \\
\hline Metastatic gestational trophoblastic disease \\
\hline Metabolic diseases \\
\hline Reversible posterior leukoencephalopathy syndrome \\
\hline Thrombophilia \\
\hline Thrombotic thrombocytopenic purpura \\
\hline Postdural puncture syndrome \\
\hline Cerebral vasculitis \\
\hline
\end{tabular}

20 weeks or more than $48 \mathrm{~h}$ after delivery, refractory to magnesium sulfate therapy, and recurrent seizures).

In conclusion, the absence of hypertension or proteinuria should not preclude diagnosing preeclampsia/eclampsia. Eclampsia or fetal distress may be an unusual presenting scenario in atypical cases before the detection of overt hypertension or proteinuria. Even minor clues in diagnoses, such as a marginally elevated $\mathrm{BP}$ or trace proteinuria, may be critical for appropriate, timely management. Obstetricians should be aware of atypical presentations, maintain a high level of suspicion, and be ready to take immediate steps. Moreover, valuable time should not be spent conducting detailed investigations.

\section{Conflict of interest}

None declared

\section{References}

1. Mattar F, Sibai BM. Eclampsia VIII. Risk factor for maternal morbidity. Am J Obstet Gynecol 2000; 182: 307-12.

2. Lubarsky SL, Barton JR, Friedman SA, Nasreddine S, Ramaddan MK, Sibai BM. Late postpartum eclampsia revisited. Obstet Gynecol 1994; 83: 502-5.

3. Sibai BM, Stella CL. Diagnosis and management of aypical preeclampsia-eclampsia. Am J Obstet Gynecol 2009; 200: 481. e1-481.e7.

4. Stella CL, Sibai BM. Preeclampsia: Diagnosis and managment of the atypical presentation. J Maternal - Fetal and Neonat Med 2006; 19: 381-6.

5. Adie V, Moodley J. Atypical eclampsia. J Obstet Gynaecol 2005; 25: 352.

6. Douglas KA, Redman CWG. Eclampsia in United Kingdom. BMJ 1994; 309: 1395-400.

7. Sibai BM, Stella CL. Diagnosis and management of atypical preeclampsia-eclampsia. Am J Obstet Gynecol 2009; 200: 481-3.

8. Sibai BM. Diagnosis, prevention, and management of eclampsia. Obstet Gynecol 2005; 105: 402-10.

9. Sibai BM, Adbella TN, Spinnato JA, Anderson GD. The incidence of non preventable eclampsia. Am J Obstet Gynecol 1986; 154: 581-6.

10. Sibai BM. Maternal-perinatal outcome in 254 consecutive cases. Am J Obstet Gynecol 1990; 163: 1049-55. 